\title{
KEY TRENDS IN EUROPEAN RETAIL BANKING AND PROSPECTS FOR THEIR DEVELOPMENT IN UKRAINE
}

\begin{abstract}
The modern banking sector of Ukraine is subject to technological influences from the financial services market of Western Europe. The article identifies key strategic directions for banking business development in the conditions of rapid technological change and transformation of the financial service consumption model. The study aims to identify the modern tendencies in banking and the prospects for implementing separate models and instruments in view of the realities of the domestic retail banking practice. The study reveals the main principles of building customer-oriented strategies in European banking. The author studies practical aspects of using new information technology as a marketing tool in the context of sales growth in the retail banking sector. In having performed the analysis of the world experience and its impact on the marketing models of domestic banks, the author identifies and suggests main directions for further development of the domestic banks that are focused on providing services to private individuals and population in general.
\end{abstract}

(C) Serhiy Kyrylenko, 2019.

Kyrylenko Serhiy, Post-graduate student, Department of International Economic Relations, Ternopil National Economic University. 


\section{Key words:}

Banks, integration of bank-to-customer interaction channels, customer behavior, banking strategies, digitalization of banking services.

JEL: G210.

\section{Introduction}

The first decade of the $21^{\text {st }}$ century in the Ukrainian banking sector was marked by its intense integration with European banking institutions. During this period, a whole set of foreign banking institutions, mostly European ones, in one or another way established representation offices in Ukraine. This was mostly realized by way of acquiring Ukrainian banks and developing them further under national legislature and with consideration for practical experience acquired while operating in their home markets in Europe and globally.

When considering such integration from the standpoint of the banking experience, management models and technologies, it should be mentioned that the Ukrainian banking sector received further impetus to development thanks to acquisition of new instruments, models and strategies. It is also worth to admit that, throughout the entire period of independence, the Ukrainian banks, especially PryvatBank, did manage to make a global contribution into the development of banking. It is sufficient to recall that it was PryvatBank that was among the pioneers which introduced a convenient SMS-banking service for their customers.

From the perspective of its social, economic and geographical dimensions, the situation in the European banking sector (together with its models and prerequisites) is very similar to modern economic realities in Ukraine. In the global context we can observe spurious growth of Asian and Arabic banks, but the peculiarities of their business models and retail banking practices are not relevant for the case of Ukraine.

In the words of bank management practitioners, banking institutions tend perform the roles of «buffers», risk intermediators and testing platforms for all sorts of regimes, as well as political and economic conditions. Banking institu- 

and prospects for their development in Ukraine

tions are the first ones to experience all significant changes in the economic and political situation. This is caused by the impact they produce on the real sector of the economy in the first place, as well as by their deep integration into the social life thanks to the retail sector of this business.

This article casts light onto the existing tendencies in European banking and elaborates on the prospects for implementation of specific models and certain scenarios in the banking sector, specifically retail banking, of Ukraine.

\section{Review of recent literature}

Theoretical and practical aspects of banking and marketing in banks were studied by many foreign and national scientists. Among foreign scientists, it is worth to mention the works of Chris R. Burggraeve, Robert L. Dansby, Chris Gassen, Malcolm McDonald, Keith Ward, Brian D. Smith, as well as other scientists who developed the foundations of modern marketing in the financial sector, specifically focusing on new technologies and their role in marketing and business-to-customer relationships. The specifics of marketing in banks, as well as the foreign experience of banking, were discussed in the works of such Ukrainian scientists as T. Vasylieva, S., Kozmenko and S. Leonov (2011), I. Lyutyi and O. Solodka (2010), L. Romanenko (2001), as well as representatives of the postSoviet space, such as O. Isaeva, V. Mamayeva and E.A.Shamkina (2012), E. Belonozhkina and S. Sazonov (2015), and others. However, the dynamic changes observed in the modern banking market call for further scientific inquiries and in-depth studies of the world's best practices of banking business organization, the process of banking strategy development, as well as for substantiation of the grounds for implementation of foreign achievements into the practice of Ukrainian banks.

The aim of this study is to identify major tendencies and trends taking place in the European retail banking sector and to substantiate the potential for their implementation into the practice of domestic banks. 


\section{Main findings}

\section{Customer journey and removing barriers in service delivery}

When considering modern tendencies in banking, especially using the example of the leading banking institutions on the European market, it is worth to acknowledge the global tendency towards «digitalization» of banking services in the first place. This direction of development is closely correlated with the ecological movement (refusal from paper flow of documents), the invincible growth of the number of cellular phone users and the development of information technologies in general. Whereas the transition to digital channels of service delivery can hardly be considered a modern tendency, the researchers' focus, however, shifts towards the path of its future development. Thus, starting from 2015, a number of banks have launched intensive in-depth investigations into the ways of improving customer experience and the possibilities of removing the barriers from bank-tocustomer interaction through digital channels of service delivery. In this context, barriers are understood as the points of customer interaction or other steps that do not significantly affect the very process of service purchase or consumption, but which can be reduced in order to speed up the process of service delivery and to create comfortable conditions for the customer. When considered from the standpoint of leading practices in digital distribution channels, the reduction of service costs, in the name of which some banks are closing down their branch offices, optimizing their channels of service delivery and discovering their Internetaudiences, is still not the key to further development. In the words of banking practitioners, the focus should shift towards deepening and improving the experience, not simply towards cutting the costs.

In the realities of domestic banking, this translates into the following practice: The majority of banking institutions consider that publishing an official webpage in social networks or creating primitive chat bots offering minimal information service is a sufficient level of «informatization». In spite of the well-developed Internet infrastructure and intense competition among financial start-ups, such banks as PryvatBank and Monobank are still standing out among other market players, pioneering the future with their innovations, especially in mobile and distance banking.

In Ukraine, the choice of a service channel still falls within the remit of the servicing bank, whereas in Europe, many banking institutions are beginning to actively interact with their customers using the means and capacities of those channels that are predominantly chosen by their customers themselves. This 

and prospects for their development in Ukraine

specific tendency stands out as one of the most promising trends for the next several years (Marous, 2018). Omni-channeling and customer interaction throughout the client's entire journey represent an important element of something that can be called «a proper and efficient way of improving the banking service". The key to successful implementation of these developments is the capabilities of banks to collect, process and analyze large volumes of data. Information enables banks to draw proper inference about both the potential customer base and the needs, wants and capacities of customers, and therefore, to offer them exactly what they are searching for and even to intentionally shape the demand for products and services in the future.

The tendencies that might seem rather futuristic in the eyes of modern banking in Ukraine, but are clearly visible in the western banking sector, are described by Brian Solis, the analyst at Altimeter Group. In his words, banks «need to pay attention to experiences of such non-financial companies as Tinder and Instagram. In the nearest future, banking should transform into something different than what it is like today. This will be something like Instagram and Tinder rather than the format of services that many global and regional banks provide today. Believe it or not, but it is design that becomes one of the most important determinants of customer experience and the key to high-quality customer service» (Marous, 2018).

Therefore, the understanding of human factor and the behavioral factor will help banks to carry out focused studies and improve the customer journey. Digital technologies are playing a secondary role in this respect, but from the practical standpoint, however, it is information technologies that enable banks to process the data and create personalized offers for their clients.

\section{Artificial intelligence and deep data analytics}

Another direction which has gained broad recognition among big players on the banking market is artificial intelligence and deep analysis of customer interaction data. Artificial intelligence and deep data analytics serve not only as a basis for service quality improvement, but also allow to significantly reduce the costs, risks and time spent on searching for optimal marketing models. Using deep data analytics is impossible without sufficient volumes of data. This is why this tendency is tightly connected with the "digitalization» of the customer journey and the marked progress in the development of digital distribution channels (Terrizzano, Pesarsi and Coppolecchia, 2018). Obviously, the use of digital sales channels provides a possibility to quickly and conveniently collect data on customer journey that will further be used for analytical purposes.

When considering the potential of introducing artificial intelligence and customer data analytics, it is worth to mention the following opportunities for sales growth: a) identification of customer needs based on user data analysis, includ- 
ing the data on non-banking and related services provided within a single banking ecosystem; b) automation of the retrieval of data on users' activity and expenses, which will enable the bank to offer them personalized products and services in the future; c) reduction of risks thanks to prompt analysis of customer data.

Among the examples of successfully implemented artificial-intelligencebased projects, worthy of mention is the technology offered to clients by mBank (Bank Rozwoju Eksportu, Poland). Thus, customers of this financial institution can obtain consultations, perform typical banking operations and solve information-related problems with the help of online chat all around the clock. It is interesting that customers communicate not with employees of the bank, but with an application based on artificial intelligence and machine learning. Having collected typical dialogues, questions and examples of bank-to-customer interaction, the developers of this software package managed to «teach» the algorithm to answer questions and provide consultations to customers, as well as to carry out transactions after the user has been identified. Worthy of mention is also the omni-channel nature of the mBank's approach. The client can initiate a conversation from a smart phone application and later continue it from a banking terminal or a laptop or a PC application. The chat-bot algorithm tracks the client's behavior and can resume the communication process from the point where it has been stopped.

The possibilities of artificial intelligence are not limited solely to customer service; they concomitantly promote growth of financial performance indicators thanks to immediate data access and preparation of expanded analytics for business decision-making. Thus, the India's Kotak Mahindra Bank developed an intellectual platform with machine learning and artificial intelligence support, which enables its top-management to promptly perform queries, request analytical information and bank's performance indicators, and build extended correlation models based on these data. Fast data processing allows to speed up the decision-making process and provide timely response to changes in the market conditions (Terrizzano, Pesarsi and Coppolecchia, 2018).

\section{Opening the bank's API for third parties}

Today, the majority of banks, especially in Ukraine, believe that providing public access to their technologies including application programming interfaces (APIs) for their business partners and third parties could pose a threat for their own security. However, one cannot but admit the explosive growth of nonbanking financial companies and start-ups which have already made themselves known with new approaches and technologies and which offer significant competition to traditional banking institutions. Over the long term, some experts are inclined to anticipate a gradual decrease in the number of traditional banks, which will lead to a situation where the market will be dominated mostly by big invest- 
Key trends in European retail banking and prospects for their development in Ukraine

ment banks and global financial and banking institutions, which have enough market power and capital to support their structures. According to banking experts, it is mutual cooperation and openness between the banks and financial start-ups that can generate the synergy effect for both of them (Ernst\&Young, 2018). First steps of such cooperation can be observed in Ukraine, including the cooperation between payment transfer services and banks, the introduction of digital electronic signature and service providers that perform identification based on it, etc.

One of the PWC's latest surveys reports that nearly $80 \%$ of bank employees believe that novel fintech companies pose a significant threat for banks in such spheres as payments processing, lending and wire transfer, which have traditionally been considered the traditional domain of the latter (Courbe, 2018). Another study carried out by PWC (DeNovo) corroborates this information indirectly: Out of all interviewed customers of banking institutions, 30\% of respondents were planning in the nearest time to switch to non-bank financial companies providing such services as wire transfer, consumer lending, payment processing, etc. Only $39 \%$ of respondents were not inclined to use services provided by any companies other than their servicing banks (Sullivan, Garvey, Alcocer and Eldridge, 2018).

Currently, only separate international financial banks and holding companies consider the concept of Value Proposition Interface (VPI), which is based on API. According to this concept, banks should shift their focus away from the capabilities of their own products onto the needs of their potential customers. Consider, for example, the following comparison. When considered from the standpoint of the regulator, the bank and the legislation, a specific product offered by the bank can have many capabilities, the majority of which are purely technical in nature. The customer, on the other hand, can operate such features as the "speed", "convenience» and "simplicity". Modern banks, when developing products and services, should clearly understand the needs of the target audience and focus on creating the interfaces that «generate value» for the latter. In practice, this translates into simple authentification, convenience of entering payment details, intuitively-understood mobile, web and desktop application interfaces, etc. The UK based Starling Bank offers its customers a possibility to use its mobile application, which features - in addition to the bank's own services the products and services of other fintech companies partnering with the bank. Thus, the users can find and receive recommendations about saving, investing, payments, lending, and other services. The system analyses the customer's activity and creates personalized offers based on the data collected. 


\section{Tight integration of bank-to-customer interaction channels with loT platforms}

There is another seemingly futuristic and currently mostly theory-based tendency, which nevertheless demonstrates high potential of being implemented into the retail banking practice in the future. Digital voice assistants, such as Google Assistant, Amazon Alexa and others have won much popularity nowadays. Some global Internet companies are embedding such instruments into separate software and hardware solutions, which are intended for home use. Such devices exemplify the new technological platform know as the «Internet of Things» (IOT). These devices are special in that they can access the global network, can be remotely administrated and programmed to perform certain actions. The loT infrastructure is not limited to digital assistants, but extends also to common devices connected to the Internet, such as household appliances. Voice commands, which are used to control such assistants, can also be used for banking services. In the future, the banking services which can be provided with the help of voice assistants may include consulting and information services, as well as payment processing, wire transfers, etc. Already today, there exist technologies that enable the users of financial and other services to use voice authentification with a high level of safety (Lichtfous, Gavray, Petrova, Martion, and Gilles, 2017).

At first thought, the potential for using digital voice assistants in banking services seems to be somewhat limited, but it is, nevertheless, worth pointing to the extended range of services that are provided by many banks thanks to inclusion of non-banking services. Combining different types of services into a single ecosystem expands both the possibilities available to customers and the range of instruments offered by the bank. In our opinion, the importance of such an approach is predetermined by the changes in the principles of interaction between the users of the Internet and intelligence-based devices, on the one hand, and their ecosystem, on the other. Today, we can observe a «simplification» of interfaces and applications. The majority of bank's potential customers and ordinary users of cellular service set a high value on their time and try to spend it frugally. That is why comfortable messengers, voice assistants and chat bots providing instant information about services or products or perform certain transactions have gained so much in popularity (Ernst\&Young, 2018b). In order to carry out a payment transaction today, it is no more necessary to visit a banking facility in person and fill out several forms by hand. It suffices to click several keys in a mobile application from any location on this planet, and the money will be transferred to the recipient whenever he or she is located. Voice interfaces open a possibility to execute banking transaction even without a cell phone or a PC. The immense interest of financial institutions in new interfaces is supported by the success of all start-ups working on the development of voice access, as well as 

and prospects for their development in Ukraine

virtual and augmented reality based technologies. Thanks to the latter, the customer can obtain visual information about location of ATMs, exchange rates, etc. by using a camera phone while on the road.

\section{Blockchain and smart contracts}

Smart contracts and blockchain based technology has already demonstrated its potential in the various spheres of economics, technology and everyday life globally. Although such technologies have certain drawbacks, which are often quickly removed by other or similar versions of the product, the potential and prospects for their usage are much more important. The financial and banking sectors, being among most resistive to security economic sectors, could benefit enormously from implementation of the above-mentioned technologies. For example, according to definitions and forecasts made by experts, the Ripple's digital tokens could replace the Swift technology for the bank's business partners and customers globally. Thanks to Ripple technology, international transfers can be carried out quickly and conveniently, with conversion into any currency of the world (Khanna and Martins, 2018).

The growing influence of information technologies induces change in the strategic planning of banking institutions. Taking into account the abovementioned tendencies, many globally active banks are systemically reconceptualizing their further development and taking a new look at strategic planning in line with modern realities. Thus, a McKinsey research study (Constancio, 2016) singles out five typical strategic plans, which can be implemented by some or other players in the banking market:

1. Going beyond the limits of own ecosystem and its expansion. This strategy involves several directions for bank development. First, a banking institution could gradually enter into new areas of business activity and expand its range of services. This can be realized by the bank itself or in close collaboration with partners, financial companies in particular. The kernel of the bank's ecosystem is formed by the classical banking services, such as lending, money transfer, payments processing, saving, and investing. An expanded ecosystem also includes non-traditional services, such as sales of third-party products, consulting and cobranding projects. Going beyond the limits of the ecosystem's kernel will open up new horizons for the bank in bank-to-customer interaction, increase the volume of data on customer journey and extend the range of tools for enhancing the loyalty of existing customers. In result of expanding the limits of their ecosystems, some banks get involved in the entirely non-banking sectors of the market. For example, Poste Italiane, the Italian financial and postal holding, provides cellular communications services, while the Dutch ING closely cooperates with financial start-ups and provides its customers with an extended range of services in cashflow planning, personalized cost accounting, etc. 
2. Universalization of services and creation of financial supermarkets. Such a strategy is being successfully implemented in many European and global banks. A number of studies show that simplified access of customers to banking products and services combined with the opportunity to simultaneously use or purchase accompanying and other services encourages potential customers to use the services of the chosen banking institution. At the same time, such an approach allows to expand the range of services and to additional attract those clients that intended to use not banking services, but the accompanying products or services. The instruments employed by financial supermarkets allow speeding up the disintermediation process and removing additional barriers in the form of intermediaries on the market of financial and other services.

3. Increasing the bank's value for the client over the entire customer journey. One of the most difficult ways for strategic development in the modern realities of domestic banks is to create added value for the client. European banks have already assessed the potential of personalized approach to each client and they undertand the need in creating the value added. For the vast majority of customers, the sole purpose of the bank is to execute certain transactions, such as payment processing, lending or wire transfer. However, those banks, which purport to cater to the needs of their customers and foster their loyalty, realize that they should give their customers something more than just selling the product or service. In the case of issuing a mortgage loan, this entails not only processing of the loan, but also the search and selection of the object of real estate, insurance processing and consulting. In addition to simply putting the customer's money on a deposit or savings account, the bank should also provide consulting services in the field of personal finance, investing, and saving (Srinivas, Fromhart, Goradia, and Wadhwani, 2018). We can find numerous other examples of such practices, but they all follow the same strategy which follows a rather simple logic: The customers should always receive a little bit more than what she or he came to get.

4. Monetizing the data and partner sales. The fact that the majority of banks possess significant volumes of data about their own clients is not a secret. However, only a small number of financial institutions actually succeeded in monetizing these data and generate profits from their use. Such an approach, first of all, creates an opportunity to make personalized offers for the clients. It also reduces advertising costs, as well as diversifies the client base and product or services development. Second, small or regional banks which lack facilities that would be sufficient to create their own financial supermarkets, can distribute their services through their partners. In some cases, a so-called «white label» strategy can be used, which involves one bank offering its services anonymously through its partner. One example of such cooperation is a partnership agreement between the ING bank and Kabbage, a financial company. Thanks to innovative application technology developed by Kabbage, thousands of customers gained access to quick scoring and short-term loan application processing, whereas 

and prospects for their development in Ukraine

ING's financial involvement helped to provide the required financing for the fintech service (Gordon and Gunupure, n.d.).

5. Quickly entering the markets where traditional approach requires much time and large capital investment. Among Ukrainian banks, Monobank is an outstanding example of such a strategy. It is only with a software application, but without a single branch office or ATM, Monobank has become one of the most fast-growing «digital» banks in the world. The ING's portfolio can boast expansion into the banking markets of nine countries without having developed either any regional network or any offline-structures. Banking and financial institutions can use this approach to tap into foreign markets, and this strategy has been proven to be more successful when realized with due planning and development (Beardmore-Gray and Elliott, 2018).

\section{Conclusions}

The above-mentioned tendencies and the respective growth strategies of European banks cannot be successfully followed by the domestic banking sector in their entirety today. However, the tendencies which are typical for European banks are clearly setting the direction for the development of the entire banking system, including the national one. Some directions, such as digital banking in the context of a separate bank, the use of deep data analytics and simplification of the customer journey are already being followed by the domestic banks.

The leading experience in the implementation of information technologies is the emphasis on convenience and the focus on the user of services. The European and global banks are actively implementing new ways of interacting with customers, where customers are the ones who determine the rules. This includes the use of intellectual chat bots and software systems, which use artificial intelligence and allow to service the customers without human intervention. The channels of bank-to-customer interaction are also changing. Today, this includes not only the web-interface of the Internet-banking service, but also chat bots, messengers and even voice assistants.

Going beyond the limits of typical banking services has become one of the major trends over the last five years. Ecosystems of some banks include such non-typical for financial structures services as providing of communication services and partner sales of products and services offered by fintech and other companies, etc. The broadening range of offered services leads to accumulation of customer data and enhanced customer loyalty, and creates opportunities for deep analytics of customer behavior and sales growth. Financial supermarket and financial marketplace are the two relatively new trends that were followed in the modern realities of Ukraine only by the state-owned Pryvatbank, which has 
started to offer its customers a range of services that do not classify as banking services.

The main thrust in the development of retail banking is made by two players - PryvatBank and Monobank. Among the top ten market leaders, however, many banks are actively implementing tried-and-true trends, developing their competences in the field of information technologies. The domestic banking sector has not yet fully overcome the crisis which has started in 2008, but the preconditions for further growth, in particular what concerns retail banking, are observed to be distinctively set today by the developments in technological progress, in particular information technologies. The main directions of future development will be based on the following technologies:

- Machine learning and artificial intelligence. The implementation of these technologies can potentially reduce banking risks and curtail the costs (staff costs in particular) of performing regular transactions, as well as provide an opportunity to quickly access data on customer behavior and create personal offerings.

- Own ecosystem development. The expansion of the range of services and cooperation with potential partners will enable the bank to offer even more products and services to their clients, thus encouraging their loyalty and improving the accuracy of analytical data on customer behavior.

- Facilitating customer journey through «re-thinking» the channels of interaction and access to banking operations. Using messengers and world's leading communications experience will offer banks an opportunity to become "convenient» for their customers, which will use their services more often and more efficiently.

\section{References}

1. Beardmore-Gray, W., Elliott, L. (2018). Your Future, Now: Five Future Trends Shaping the Retail Banking Sector. Knight Frank LLP. Retrieved from https://content.knightfrank.com/research/1424/documents/en/global-retailbanking-sector-trends-2018-5189.pdf.

2. Belonozhkina, E. A., Sazonov, S. P. (2015). Analyzing the application of marketing tools at the current stage of the banking market development: Foreign experience and Russian practice. [Analiz primeneniya instrumentov marketinga na sovremennom etape razvitiya bankovskikh uslug: zarubezhnyy opyt i rossiyskaya praktika]. Financial Analytics: Science and Experience, 26, 2-9. (in Russian). 

and prospects for their development in Ukraine

3. Constâncio, V. (November 2016). Challenges for the European banking industry. Retrieved from https://www.researchgate.net/publication/ 313900840 _Challenges_for_the_European_banking_industry.

4. Courbe, J. (2018). Financial Services Technology 2020 and Beyond: Embracing Disruption. Retrieved from https://www.pwc.com/gx/en/financialservices/assets/pdf/technology2020-and-beyond.pdf.

5. Ersnst\&Young (2018a). The changing shape of international banking and the future of Europe. [Bank Governance Leadership Network]. Retrieved from https://www.ey.com/Publication/vwLUAssets/EY-the-changing-shape-ofinternational-banking-and-the-future-of-Europe/\$FILE/ey-the-changingshape-of-international-banking-and-the-future-of-Europe.pdf.

6. Ernst\&Young (2018b). Global banking outlook 2018. Pivoting toward an innovation-led strategy. Retrieved from: https://www.ey.com/Publication/ vwLUAssets/ey-global-banking-outlook-2018/\$File/ey-global-bankingoutlook-2018.pdf.

7. Gordon, F., Gunupure, S. (n.d.). Banking strategies for the future: Looking ahead to 2020. Retrieved from https://www.atkearney.com/documents/ 10192/4598780/Banking+Strategies+for+the+Future.pdf/cc0f08b2-e5f6-49bf899d-d1699f45dec0.

8. Isayeva, E. V., Mamaeva, V. Yu., Shamkina, E. A. (2012). Implemening strategy of partner relationship marketing in a bank: Foreign experience. [Realizatsiya strategii marketinga partnerskikh otnosheniy $v$ banke: ispolzovaniye zarubezhnogo opyta]. Vestnik Omskogo Universiteta. Seria «Ekonomika", 3, 127-131. (in Russian).

9. Khanna, S., Martins, H. (April 2018). Six digital growth strategies for banks. Retrieved from https://www.mckinsey.com/business-functions/digital-mckinsey/ our-insights/six-digital-growth-strategies-for-banks.

10. Kozmenko, S. M., Vasylieva, T. A. Leonov, S.V. (2011). Marketing of banking innovations. [Marketynh bankivskyh innovatsii]. Marketynh i Menedzhment Innovatsii, 1, 13-28. (in Ukrainian).

11. Lichtfous, M., Gavray, G., Petrova, E., Martino, P., Gilles, F. (2017). The future models of banking in Europe. Retrieved from https://www2.deloitte.com/ content/dam/Deloitte/lu/Documents/financial-services/Banking/lu-the-futuremodels-banking-in-europe-062017.pdf

12. Lutyi, I. O., Solodka, O. O. (2010). Bank Marketing [Textbook]. [Bankivskyi Marketynh]. Kyiv, Tsentr Uchbovoyi Literatury. (in Ukrainian).

13. Marous, J. (2018). Top 10 Retail Banking Trends and Predictions for 2018. Retrived from https://thefinancialbrand.com/69180/2018-top-banking-trendspredictions-outlook-digital-fintech-data-ai-cx-payments-tech/. 
14. Romanenko, L. F. (2001). Bank Marketing [Monograph]. [Bankivsktyi Marketynh]. Kyiv, Vydavnychyi Dim «In Yure». (in Ukrainian).

15. Srinivas, V., Fromhart, S., Goradia, U., Wadhwani, R. (2018). Banking Outlook: Accelerating the transformation. Retrieved from https://www2.deloitte.com/ content/dam/Deloitte/global/Documents/Financial-Services/gx-fsi-dcfs-2018banking-outlook.pdf

16. Sullivan, B., Garvey, J., Alcocer, J., Eldridge, A. (2018). Retail Banking 2020: Evolution or Revolution? Retrieved from https://www.pwc.com/gx/en/bankingcapital-markets/banking-2020/assets/pwc-retail-banking-2020-evolution-orrevolution.pdf.

17. Terrizzano, A., Pesaresi, S., Coppolecchia, A. (2018, October 15). Innovative trends in retail banking. Retrived from https://www.accenture.com/ acnmedia/PDF-78/Accenture-EFMA-Innovative-Trends-in-Retail-Banking.pdf. 